\title{
CONTRIBUIÇÃO A UMA "HISTÓRIA DOS DE BAIXO" DO SINDICALISMO
}

Adhemar Lourenço da Silva Jr.*

\section{INTRODUÇÃO}

Embora existam muitos estudos históricos sobre sindicalismo e trabalhadores no Brasil - inclusive os que abordam o período da República Velha -, um resenhista (Wolfe, 1993a) observou que a "not-so-new "new social history'" brasileira teria dificuldades em perceber o trabalhador comum que, envolvido ou não em greves e outros movimentos, é visto como mera matéria moldável, seja pelo discurso das lideranças, seja pelo do patronato ou do Estado. Assim, a historiografia centrar-se-ia demasiado no discurso desses agentes sociais, ignorando até que ponto o ideário das lideranças operárias, por exemplo, é partilhado ou reinterpretado por aqueles que compóem o que chamamos hoje de "base (sindical)". ${ }^{1}$

- Mestre em História - UFRGS.

Agradeço aos profs. e pesquisadores Ana Frega, Cláudia Mauch, José Remedi e Rodolfo Porrini por suas informações e observações realizadas no decorrer desta pesquisa.

1 Apesar do tom excessivamente institucional, preferi utilizar a expressão "base (sindical)" em lugar de ranks (ou ainda: rank and file), embora a última corresponda melhor ao objeto desta exposiçăo. Wolfe atribui a lacuna a determinadas perspectivas de análise, mas creio que a carência de fontes - especialmente para períodos cujos testemunhos orais já morreram - acentua o problema, mesmo porque sua própria abordagem do movimento operário da República Velha se ressente da mesma lacuna, ainda que matizada por suposiçōes não muito fundamentadas (1991a, 1991b e 1993b; French, 1991).

Estudos Ibero-Americanos. PUCRS, v.XXI, n.1, p. 61-83, julho, 1995 
Com este texto, descreverei a "base sindical" da organização que congregava os trabalhadores das pedreiras e do calçamento, ressaltando ainda os condicionantes de sua atitude com relação à agitação operária de Porto Alegre em 1917. Embora organizados nessa cidade em único sindicato - e seja mesmo possível encontrar denominações emic para a categoria como um todo - é patente a clivagem entre dois ofícios: os canteiros (trabalhadores das pedreiras) e os calceteiros (trabalhadores do calçamento). ${ }^{2}$ Desconheço estudos específicos sobre canteiros ou calceteiros, embora sejam encontradiças as referências bibliográficas a associações de trabalhadores em pedreiras de outras cidades do Brasil. ${ }^{3}$ Ainda que o presente texto centre-se no estudo da categoria em Porto Alegre, até o final da exposição serão fornecidos subsídios que possibilitam algumas generalizações para outras cidades do Brasil, Argentina, Uruguai e, no limite, Península Ibérica.

As escassas referências a esse tipo de trabalhador na Porto Alegre do século XIX contrastam com a agitação verificada em meados da década de 1910, quando se inicia um tímido processo de reforma urbana, parcialmente bloqueado pelas dificuldades decorrentes da Primeira Guerra. Embora os canteiros de Porto Alegre já gozassem da jornada de 8 horas - conquistada na greve de 1906 (A Luta, 10/10/1906) -, é a partir de 1916, por ocasião do recalçamento da cidade e construção do cais, que a atividade reivindicatória cresce, com demandas concernentes a jornada de trabalho, descanso semanal, salários, e, principalmente, controle sindical sobre a oferta de mão de obra.

A fonte que permitirá a descrição da "base" da categoria resulta de um evento ocorrido em 19 de março de 1917. Uma greve de calceteiros e canteiros, deflagrada em 8 de março desse ano, teve de combater não

2 Foram encontradas duas denominações emic para a categoria como um todo: uma fonte refere-se aos "trabalhadores em pedra", termo que provavelmente abrangia pedreiros, canteiros, marmoristas e, quiçá, calceteiros (AVT, 17/4/1909, p. 4); outra fonte nos fala dos "trabalhadores do calçamento", divididos entre "trabalhadores das pedreiras" e "trabalhadores da rua", cf. A Luta, 31/5/1916, p. 4.

Ao longo deste texto, utilizo o termo "canteiros" para designar os trabalhadores que, nas pedreiras, trabalham com pedras, independente de serem eles oficiais canteiros, oficiais macaqueiros ou oficiais encunhadores, o mesmo valendo para o termo "calceteiro", que designa os oficiais calceteiros e oficiais cavouqueiros.

3 Uma das poucas e sumárias referências a calceteiros encontra-se em Gitahy, 1992, p. 68. Sobre a mesma agitação de calceteiros em Santos, veja-se também AVT, $15 / 6 / 1909$ p. 4 e $29 / 7 / 1909$, p. 3. 
só a intransigência patronal no atendimento das reivindicações (que versavam sobre a demissão de dois capatazes), mas também os "carneiros" - fura-greves contratados para os postos vagos. No dia 19, um grupo estimado entre 100 e 200 trabalhadores atacou uma turma de 30 carneiros do calçamento, com um saldo de vários feridos, 4 baleados, um dos quais morreu. Os três volumes do processo-crime por homicídio apresentam depoimentos de 91 trabalhadores no inquérito, parte dos quais detida em "batidas policiais" (sic). Havendo o prazo legal de 24 horas de detenção para averiguações e formação de culpa, até a madrugada do dia 20 trabalharam 5 amanuenses nos registros, que serviram para a composição da amostra que ora me serve de fonte. Além dos depoimentos, constam nos autos exemplares de folhetos, panfletos, jornais da categoria e extratos da imprensa de Porto Alegre - alguns desses jornais inexistentes em outros arquivos -, fontes que serão também aqui utilizadas. ${ }^{4}$

\section{A composição da amostra: observações gerais sobre a categoria}

É difícil saber exatamente quantos canteiros, calceteiros e oficiais de classes anexas trabalhavam em Porto Alegre, ou, pelo menos o número total de sindicalizadọs. O Censo de 1920 (Brasil, 1920) declara haver 139 trabalhadores em pedreiras na cidade, embora o ofício de canteiro estivesse indiscriminado no interior da rubrica "Indústrias de edificação" e inexista, dentro ainda dessa rubrica, o ofício de calceteiro. Embora a imprensa de 1917 não forneça dados de todo confiáveis, eles se adequam melhor ao verificado no processo: Segundo o CP (13/3/1917), haveria cerca de 600 canteiros e calceteiros em greve, o que corresponderia à "maior parte" dos trabalhadores (Pereira, 1950, p. 536),

4 Processo-crime n. 856. Réus: Ângelo Cavanellas e outros. Maço 53, Estante 2. 1917. Tribunal do Júri. Arquivo Público do Estado do Rio Grande do Sul. A partir de agora essa fonte será referida como Processo. Esta foi a fonte principal do Cap. I de Silva Jr., 1994a, p. 29-124. Nessa ocasião, utilizei uma amostragem que ainda incluía dados obtidos na imprensa, em um total de 126 trabalhadores. Para este artigo contentei-me em trabalhar apenas com os dados do Processo, mesmo porque a única diferença sensível entre ambas amostras dizia respeito ao fato da imprensa publicar nomes, idades e ofícios dos carneiros, além dos trabalhadores que tinham vários nomes, dados que não se apresentaram como relevantes nos levantamentos aqui efetuados. 
mesmo porque "poucos operários não aderiram à greve" (AF, 19/3/1917, p. 7). Outra fonte nos fala de "más de mil obreros de las canteras" (LB, $2^{\mathrm{a}}$ quincena de marzo de 1917, p. 4), mas supõe-se que tal número inclua os pedreiros e carpinteiros da construção do cais que, embora trabalhassem para a mesma empresa, entraram em greve com outra pauta de reivindicações (CP, 15/3/1917).

Para compor a amostragem utilizada, 3 dos 91 depoimentos foram retirados do Processo: dois pertencentes a funcionários administrativos da Empresa do Calçamento (um guarda-livros e um "encarregado do pessoal") e o depoimento de um caixeiro (ver-se-á mais tarde seu papel na greve). Desse modo, temos uma amostragem de 88 trabalhadores, o equivalente a $14,67 \%$ (dos 600) da categoria. Embora creia que essa percentagem seja exagerada, trabalharei com essa possibilidade, de qualquer modo atento a possíveis distorções.

Quase 2/3 dos trabalhadores do calçamento em Porto Alegre (cf. especificado no Anexo I) seriam espanhóis e portugueses, o que não surpreenderia, tendo em vista a elevada imigração no período da República Velha. No entanto, os trabalhadores em pedra não seriam uma categoria típica em Porto Alegre, pois os dados do Censo de 1920 apontam tão somente $30 \%$ de estrangeiros no mercado de trabalho da cidade. O elevado número de estrangeiros ocorria, por um lado, por causa da demanda de mão de obra especializada, e por outro, devido à capacidade profissional desses imigrantes. Posições antipáticas à greve atribuem ao estrangeiro a culpa pela agitação (AF, 20/3/1917), mas a facilidade de obter emprego nesse tipo de função em Porto Alegre é atestada pelo encarregado do pessoal da Empresa, ainda que o mesmo acredite nessa culpabilidade:

....as greves tem sido contínuas desde que aqui aportaram, os operários espanhóis e portugueses em busca de serviços, aparecendo no escritório da empresa, conforme a profissão são aceitos e distribuídos (Processo, fl. 65).

O espectro profissional da "base" do Sindicato dos Canteiros, Calceteiros e Classes Anexas é amplo, como se pode ver ainda na Tabela I do Anexo 1. O maior número de profissionais (35) declarou-se "canteiro", embora essa denominação pareça englobar não só o ofício de canteiro, mas também os ofícios de encunhadores e macaqueiros: apenas 3 se declararam "encunhadores", mas supõe-se que outros encunhadores (assim como "macaqueiros") existissem e se declarassem genericamente 
mesmo porque "poucos operários não aderiram à greve" (AF, 19/3/1917, p. 7). Outra fonte nos fala de "más de mil obreros de las canteras" (LB, $2^{\mathrm{a}}$ quincena de marzo de 1917, p. 4), mas supõe-se que tal número inclua os pedreiros e carpinteiros da construção do cais que, embora trabalhassem para a mesma empresa, entraram em greve com outra pauta de reivindicações (CP, 15/3/1917).

Para compor a amostragem utilizada, 3 dos 91 depoimentos foram retirados do Processo: dois pertencentes a funcionários administrativos da Empresa do Calçamento (um guarda-livros e um "encarregado do pessoal") e o depoimento de um caixeiro (ver-se-á mais tarde seu papel na greve). Desse modo, temos uma amostragem de 88 trabalhadores, o equivalente a $14,67 \%$ (dos 600$)$ da categoria. Embora creia que essa percentagem seja exagerada, trabalharei com essa possibilidade, de qualquer modo atento a possíveis distorções.

Quase 2/3 dos trabalhadores do calçamento em Porto Alegre (cf. especificado no Anexo I) seriam espanhóis e portugueses, o que não surpreenderia, tendo em vista a elevada imigração no período da República Velha. No entanto, os trabalhadores em pedra não seriam uma categoria típica em Porto Alegre, pois os dados do Censo de 1920 apontam tão somente $30 \%$ de estrangeiros no mercado de trabalho da cidade. O elevado número de estrangeiros ocorria, por um lado, por causa da demanda de mão de obra especializada, e por outro, devido à capacidade profissional desses imigrantes. Posições antipáticas à greve atribuem ao estrangeiro a culpa pela agitação (AF, 20/3/1917), mas a facilidade de obter emprego nesse tipo de função em Porto Alegre é atestada pelo encarregado do pessoal da Empresa, ainda que o mesmo acredite nessa culpabilidade:

....as greves tem sido contínuas desde que aqui aportaram, os operários espanhóis e portugueses em busca de serviços, aparecendo no escritório da empresa, conforme a profissão são aceitos e distribuídos (Processo, fl. 65).

O espectro profissional da "base" do Sindicato dos Canteiros, Calceteiros e Classes Anexas é amplo, como se pode ver ainda na Tabela I do Anexo 1. O maior número de profissionais (35) declarou-se "canteiro", embora essa denominação pareça englobar não só o ofício de canteiro, mas também os ofícios de encunhadores e macaqueiros: apenas 3 se declararam "encunhadores", mas supõe-se que outros encunhadores (assim como "macaqueiros") existissem e se declarassem genericamente 
"canteiros", mesmo porque as tabelas de vencimentos contemplavam tais ofícios (CP, 11/6/19166; AF, 24/3/1917). Nas ruas trabalhavam turmas com calceteiros, cavouqueiros e serventes, sob o comando de um capataz, embora, na amostra, nenhum integrante tenha-se declarado "cavouqueiro", atividade que consistia na preparação do terreno para o assentamento de pedras, responsabilidade do calceteiro. Tanto nas pedreiras, como nas ruas, também havia ferreiros, trabalhando "no reparo da ferramenta", bem como outros oficiais (mineiros, oleiros, marmoristas, pedreiros), cujo aprendizado profissional os permitia exercerem também a cantaria.

A idade média da amostra é de 28 anos e 8 meses (distribuídos cf. o Gráfico 2): observe-se que $52 \%$ dos trabalhadores tem idades entre 21 e 30 anos. Embora fosse possível "lavrar pedras" autonomamente, foi encontrado um único caso de não-assalariamento (Processo, fl. 69). Inobstante, havia casos de trabalho por peça ("trabalho a gancho" cf AVT, 1/1/1915; v. também 13/1/1909) e greves por aumento do valor da peça $(\mathrm{CM}, 21 / 3 / 14)$. Há também situações nas quais, lado a lado, trabalhavam encunhadores e canteiros - estes últimos remunerados por peça e aqueles com jornada superior a 12 horas diárias (AVT, $5 / 6 / 1914)$.

\section{Condições de vida e trabalho: a migração}

Exceção feita às pedreiras de Capão do Leão e Morro Redondo (em Pelotas, Rio Grande do Sul), há pouco registro de mecanização do trabalho. Inventariou-se nesses locais que, administrados pela Compagnie Française, forneciam material para a construção do Porto de Rio Grande -4 guindastes a vapor, 14 guindastes elétricos, 2 enxadas a vapor (escavadeiras), 4 eletro-geradores, 2 "grupos pneumáticos" (compressores de ar), 1 motor locomóvel, forjas e máquinas para a reparação de ferramentas, 32 "martelos perfuradores (revolvers)", "instalação para britar pedras" (Rio Grande do Sul,1920, p. 158-161). Afora os guindastes e a instalação de carros sobre trilhos para o transporte de blocos de rocha (CP, 29/6/1918; AVT, 1/8/1908), poucas máquinas existiriam em outras pedreiras. No caso do calçamento, eventualmente utilizar-se-iam "cilindros" ou "compressores" a gasolina para a preparação do terreno (Porto Alegre, 1916-1917). 
O trabalho nas pedreiras, em especial, envolvia riscos de acidentes de quedas, seja de pessoas, seja de blocos de rocha (CP, 29/6/1918; CM, 15 e 21/1/1914; DP, 26/2/1914). Qualquer que fosse o grau de mecanização do trabalho, o custo da execução do calçamento era absorvido em grande parte pela remuneração da mão de obra. Considerando apenas o custo da mão de obra envolvida na pavimentação, as despesas com sua remuneração oscilariam, conforme estatísticas, entre 30\% (Porto Alegre, 1916-1917) e 49\% (Paraná, 1983, p. 13) das despesas totais. O maior problema do calçamento de Porto Alegre era, no entanto, a dificuldade em encontrar oficiais, problema verificado não só em 1897 - quando atribuía-se a lentidão das obras ao fato de que muitas vezes os calceteiros tinham "de largar o martelo (...) para auxiliar os cavouqueiros" (Porto Alegre, 1897, p. 17) - como 30 anos após, quando as autoridades lamentavam a "falta de calceteiros e socadores, serviço que exige habilitação do operário" (AF, 23/10/1926, p. 5).

O problema agrava-se a partir de 1913 , com a construção intensiva de esgotos. Como a obra implicava "o revolvimento do solo", a Intendência Municipal de Porto Alegre aproveitou para trocar o calçamento das ruas em grande escala. Uma grande empreiteira venceria a concorrência pública aberta em 1915 , para pavimentar $515.568 \mathrm{~m}^{2}$. Tal empresa também obteria a concessão para a exploração de pelo menos duas pedreiras, de modo a baixar o custo de produção do material. Embora empresas de Porto Alegre concorressem, a vencedora proveio do Rio de Janeiro, já tendo feito trabalhos semelhantes também em São Paulo e Salvador (Porto Alegre, 1915, p. 46-48). A Empresa do Calçamento ofereceu um custo inferior da mão de obra pois não aproveitaria apenas os poucos trabalhadores especializados de Porto Alegre, buscando-os alhures. "Agentes" (intermediários na colocação de mão de obra) do Rio de Janeiro ofereciam a canteiros e calceteiros a jornada de 8 horas e uma remuneração satisfatória. Nessas condições era fácil obter trabalhadores; não só devido à "crise por que atravessa o mundo proletário" (desemprego e baixos salários), como também por causa do deslocamento de uma cidade à outra ser pago pelo Ministério da Agricultura (A Luta, 31/5/1910, p. 4).

Mesmo que fossem vantajosos os estímulos para aumentar a oferta de mão de obra em Porto Alegre, seria difícil verificar o êxito dessa medida, se não houvesse uma constante mobilidade desses trabalhadores. É surpreendente verificar a rotineira migração de trabalhadores em 
pedra, auxiliada por uma rede de obtenção de mão de obra que extrapola o município ou as regióes próximas. $\mathrm{O}$ trabalhador exerce o ofício continuamente, mesmo que para isso tenha que se transladar de uma cidade à outra, em busca de melhores salários, condições de trabalho ou simplesmente emprego. ${ }^{5} \mathrm{O}$ calceteiro português Delfino dos Santos, que há 11 anos trabalhava em diversas cidades do Brasil, provinha do Rio de Janeiro "com o fim de empregar-se no calçamento desta cidade [Porto Alegre] o que logo conseguiu". O ferreiro espanhol Severino Gomes, há 4 anos no Brasil, já trabalhara em Santos, São Paulo e Rio Negro (Paraná) antes de vir a Porto Alegre. O oleiro espanhol Longuiño Monumento provinha de Pelotas, onde já trabalhava em pedreiras. O canteiro espanhol Daniel Quintas, desgostoso após a greve, tencionava ir-se a Buenos Aires. O canteiro português Manoel Monteiro chegara há 2 anos em Porto Alegre (não no Brasil) (Processo, fls. 17-19 e 87-90). Pode-se supor, ainda que os dados não permitam uma conclusão peremptória, que os solteiros migrassem mais facilmente, pois, enquanto $54 \%$ dos riograndenses da amostra eram casados, $61 \%$ dos não-rio-grandenses eram solteiros.

A migração ocorria sempre que o mercado de trabalho oferecia melhores oportunidades alhures. Quando derrotados em uma greve, os trabalhadores optavam por migrar, como os 150 trabalhadores das "canteras del Minuano" em Montevideo que rumaram para Buenos Aires em 1917 (D’Elia, Miraldi, 1986, p. 127). Cabe lembrar que os marmoristas (outro ofício ligado a pedras) iniciadores da greve geral de 1906 em Porto Alegre, acabaram "embarcando para o Rio de Janeiro em busca de trabalho", inconformados com a jornada de 9 horas quando sua reivindicação era de 8 (A Luta, 29/9/1906, p. 2 e 10/10/1906, p. 2).

A rede de obtenção de mão de obra envolvia agentes em diferentes cidades, dentre as quais, como já foi mencionado, o Rio de Janeiro. Não é preciso supor, entretanto, que essa rede fosse restrita aos limites do Estado Nacional. A vinda do trabalhador europeu para o Novo Mundo é para "fazer a América" e não especificamente o Brasil, a Argentina ou o Uruguai, sendo possível encontrar "agentes" em diferentes cidades. Isso fazia com que a percepção do mercado de trabalho por canteiros e

5 O tema da migraçâo interna de trabalhadores na República Velha ainda merece mais estudos. Para o caso dos trabalhadores sergipanos, normalmente contratados para grandes obras no sul e sudeste do Brasil, veja-se Passos Sobrinho, 1992. 
calceteiros não fosse local ou nacional, mas constituída por um espaço amplo e descontínuo, envolvendo diversas cidades da América do Sul e Península Ibérica. ${ }^{6}$

A migração de oficiais para novas e diferentes cidades fazia com que se reproduzissem semelhantes fenômenos em vários locais, semelhança já verificada no que concerne à comensalidade, co-habitação e remuneração em vales utilizados para compra em armazéns patronais. Os três fenômenos ocorrem em Porto Alegre (1916 e 1917), Cotia (São Paulo) em 1917, em Montevideo (1901), e, na Argentina, em Tandil (1908-1909), Los Pinos e Balcarce (1913) (CP, 17/7/1917; Zubillaga, Balbis, 1988, p. 106; Marotta, 1975, p. 371 e 499). Alguns calceteiros em Porto Alegre habitavam, faziam refeições e sesteavam em um acampamento na zona urbana (OD). Também em Pelotas havia "pequena[s] casa[s] de madeira" para os trabalhadores das pedreiras de Capão do Leão (OP, 11/4/1914, p. 2). Na Colônia Africana, em Porto Alegre, 32 trabalhadores em pedra foram detidos em batidas nos restaurantes, tendo 96 deles, entre grevistas e não-grevistas declarado morar no bairro (OD; CP 20/3/1917). Embora houvesse pedreiras nas proximidades da Colônia Africana, muitos dos canteiros, no período em que cortavam pedras em locais distantes, declararam estar "sem residência". A chegada em uma nova cidade, "sem dinheiro, sem relações" (ALuta, 31/5/1916, p. 4) fazia os trabalhadores procurarem seus patrícios e colegas, compartilhando a moradia e dividindo as tarefas domésticas (Processo, fls. 95-97).

A tentativa de manter incólumes determinados laços frente à constante migração também levava irmãos a tomarem os mesmos ofícios e rumos. Ao longo do Processo foram encontrados quatro casos de irmãos que trabalhavam e moravam juntos: os Rivera (Félix e Dorotheo), os Salles (Feliciano, José e Francisco), os Peralvo (Luiz e Fernandes) e os Quintas (Jaime e Daniel). Possivelmente também eram irmãos os quatro carneiros de Ribeirão Pires (São Paulo) em 1913: Antonio, Pasqual, José e Pedro Muselli (AVT, 1/12/1913). Por não comparecer ao trabalho no $1^{\circ}$ de maio de 1908 , o canteiro M. Barbosa e seu irmão foram demitidos (AVT, 6/12/1908).

6 Sobre agentes e migraçōes no e para o Uruguai, veja-se: Zubillaga, Balbis, 1988, p. 23; LB, $1^{\mathrm{a}}$ quincena de julio de 1915 , p. $3,2^{\mathrm{a}}$ quincena de febrero de 1916 , p. 3 e la quincena de noviembre de 1916, p. 3. Para a Argentina, veja-se AVT, 17/4/1909, p. 3; Marotta, 1975, p. 501. Para Portugal, veja-se AVT, 1/6/1913, p. 2 e 1/9/1913, p. 4. Sobre a percepção do mercado de trabalho, uma reflexão preliminar encontra-se em Silva Jr., $1994 b$. 
A convivência dentro e fora do local de trabalho muito contribuía para o estabelecimento de fortes vínculos afetivos havendo, em Porto Alegre, referências aos "irmãos de classe" (OD); Rebelião, 14/3/1917, p. 4). Mas tais vínculos não são necessariamente amistosos: são comuns os registros de violência física (ou ameaças) nas relações dos membros da "base" dos canteiros e calceteiros. Após uma greve em junho de 1916, canteiros que trabalhavam próximos à zona urbana de Porto Alegre foram enviados, com anuência do sindicato, para longe do centro, para evitar atritos com os carneiros (CP, 11/6/1916). A greve de março de 1917, da qual resultaria o Processo, originou-se de uma briga entre dois calceteiros de uma turma e da intervenção do capataz, irmão de um daqueles, ameaçando o terceiro com uma faca. Semanas antes, o sindicato conclamava um boicote à pedreira de Rodolpho River, por ter ele "a pretensão de falar com desaforos e despotismo a seus operários, desafiando-os belicosamente com armas na mão" (Processo, fl. 56). Manoel Domingues morava no mesmo Hotel dos Viajantes em que morava o militante sindical Isidro Vicente. Não tendo o primeiro entrado em greve em 1917, o segundo tornou-se "seu desafeto" (Processo, fls. 208-209). Em Pelotas, verificaram-se pelo menos dois casos de ferimentos - um voluntário e outro acidental - com armas de fogo portadas por trabalhadores durante o serviço (CM, 24/1/1914; DP, 4/3/1914).

A utilização corrente de violência física contra carneiros (ou policiais que os protegiam) não foi exclusiva do Rio Grande do Sul, tendo sido também em verificada em outras cidades.7 Também não é difícil encontrar relatos de agressões em meio a conflitos sindicais, marcados por expressões envolvendo a honra do ofício. Em abril de 1909, os canteiros do Rio de Janeiro reivindicaram aumento salarial, conclamando: "Chega de cobardia! Façamos cumprir a tabela [de salários] embora para isso seja preciso empregar a violência." (AVT, 1/5/1909, p. 4). No decorrer dessa mesma greve houve alguns "traidores" que logo abandonaram o trabalho, ficando "sem vontade de trabalhar, tal o susto que levaram" (AVT, 22/6/1909, p. 2).

7 Para Rio de Janeiro e Santos, veja-se AVT, 30/10/1909, p. 4 e 1/7/1913, p. 3; para Montevideo e Colonia, veja-se LB, $2^{a}$ quincena de febrero 1916. p. 2, Zubillaga, Balbis, 1985 , p. 129 e ss. e Machado, 1972, p. 277-278. 


\section{As reivindicações da categoria e as relações com o sindicato}

É difícil verificar se os intensos laços afetivos precediam ou decorriam do "orgulho do ofício" que permeava as reivindicações e a elevada adesão às greves deflagradas. Não era incomum que a agitação sindical buscasse suas justiticativas na necessidade de reagir ao "estado de desmoralização da arte da cantaria" (AVT, 29/11/1908, p. 3) e outras expressões desse jaez, envolvendo a dignidade "de um nome glorioso" (AVT, 3/8/1909, p. 3), maculado por "traidores" (termo abundante na documentação) "sem um pingo de vergonha" (AVT, 15/8/1908, p. 2). O fato é que, ao longo das páginas da Voz do Trabalhador há constantes referências à pujança do Sindicato dos Operários das pedreiras daquela cidade.

Desde 1916 também são constantes esses tipos de referências à organização sindical de Porto Alegre. Chegados em Porto Alegre em março de 1916 com a promessa de trabalharem 8 horas diárias, a primeira greve ocorreu dias após, quando a jornada foi arbitrariamente elevada em uma hora. O capataz da turma de calçamento, atendendo a protestos dos trabalhadores, foi ter com o engenheiro responsável, que respondeu pela negativa. Uma greve vitoriosa de 45 dias foi deflagrada e garantiu as 8 horas de trabalho e a "efetividade da tabela" de vencimentos, ou seja, que, finda a greve, os salários seriam pagos conforme acordado (CP, 7/5/1916, p. 5 e $11 / 6 / 1916$, p. 4).

Nova greve vitoriosa ocorre em setembro de 1910, cujos resultados causam admiração:

$1^{\mathfrak{2}}$ - Trabalhar apenas 8 horas por dia; $2^{\mathfrak{Q}}$ - Não aceitar a hora extraordinária, salvo se esta for paga duplamente; (...) $5^{\circ}-\mathrm{Se}$ a empresa quiser trabalhar aos domingos, deverá pagar $50 \%$ sobre os ordenados; $6^{2}$ - Readmissão de todo o pessoal demitido; $7^{\mathfrak{Q}}$ - Não aceitar tarefa fixa; $8^{\mathrm{Q}}$ - Não poder a empresa despedir operário sem motivo justificado.

A greve ocorreu por causa da demissão de 11 calceteiros que não aceitavam "tarefa fixa" (determinada metragem de rua calçada por dia trabalhado): havia capatazes exigindo o calçamento diário de $24 \mathrm{~m}^{2}$, quando o máximo que os calceteiros admitiam fazer, também pela ausência de material, eram 15 ou $16 \mathrm{~m}^{2}$. Deflagrada no dia 7 , desde a manhã seguinte não havia nenhum calceteiro trabalhando: adesão total 
da categoria. No dia 8 , o sindicato declara o "apoio moral e material" à greve dos calceteiros. Uma comissão de trabalhadores foi presa quando ia ter com o engenheiro responsável pela zona e outra comissão dirigiuse, desta vez, ao Vice-Presidente do Estado em exercício, que telefonou ao delegado de polícia "ordenando que soltasse os presos".

No dia 9, 4 calceteiros voltaram ao trabalho, possivelmente receosos com a ameaça de lock out, mas, tempo depois, chegou-se a um acordo: as reivindicações seriam integralmente aceitas, à exceção dos vencimentos aos 11 operários que haviam sido demitidos, porque estes não produziam o suficiente. Em 11 de setembro os calceteiros voltaram ao trabalho e o sindicato nomearia uma comissão para verificar se, de fato, os que a Empresa queria demitir produziam pouco. Se a comissão concordasse com o diagnóstico da Empresa, os 11 calceteiros receberiam, com anuência do sindicato, salários reduzidos (CP, 8 a 12/9/1916).

A greve de março de 1917, da qual se originou o Processo, embora tenha resultado na morte de um "irmão de classe", não foi derrotada, tampouco levou à condenação dos acusados, que foram absolvidos um ano após por falta de provas. Em 1918, quando as obras de calçamento já haviam sido encampadas pela Intendência Municipal, foi deflagrada nova greve que, mesmo movida contra o poder público, foi vitoriosa (Notícia, 2/4/1918; CP, 17/4/1918). Em 1921 dizia-se que os canteiros promoviam "concorridíssimas assembléias" (O Syndicalista, mar./1921, p. 4) e, em 1927, sua entidade era considerada o único sindicato sob orientação de anarquistas realmente existente em Porto Alegre (Rodrigues, 1979, p. 74), tendo ainda promovido exitosa paralisação em protesto pela execução de Sacco e Vanzetti (Diário de Notícias, 9/8/1927).

Várias das greves verificadas, não só em Porto Alegre, como em outras cidades, envolviam o controle do sindicato sobre a oferta local de mão de obra. Embora a migração fosse facilitada pela presença de "agentes" em diferentes cidades, recomendava-se que informações sobre os locais de destino fossem obtidas junto aos sindicatos, pois os "agentes" poderiam omitir condições prejudiciais aos trabalhadores. Os sindicatos tornavam-se, assim, concorrentes dos "agentes" no processo de intermediação de mão de obra, obtendo muito de sua força e penetração na categoria. Da amostra de 88 trabalhadores utilizada, 35 se declararam sindicalizados e apenas 4 se declararam não-sindicalizados, apesar dessa última resposta ser a mais adequada frente ao interrogatório policial (de 49 trabalhadores, incluindo dois capatazes, não há registro). Vários trabalhadores se diziam sindicalizados porque todos o eram, mas supõe- 
se que isso se restringia aos oficiais: José Fernandes, possivelmente nascido na cidade, declarou que "sendo simples servente, não é sócio de sociedade alguma" (Processo, fl. 85). Também poderia ser investigado o fato de que a média de idade dos não-sindicalizados ser inferior ao do total da amostra ( 24 contra 28 anos), denunciando o processo de sindicalização como parte do aprendizado (ou da tradição) do ofício. ${ }^{8}$

Se o processo de intermediação da mão de obra pelos "agentes" poderia ser prejudicial ao trabalhador, havia um ônus na intermediação feita pelos sindicatos: era a associação compulsória. Todos os trabalhadores deveriam ser sócios e pagar a contribuição sindical. Os estatutos do sindicato em Porto Alegre previam castigos a quem nảo comparecesse com determinada freqüência às assembléias da categoria (Processo, fls. 42-46). A sindicalização compulsória de todos os oficiais - e sua contrapartida, que é a exigência que o patronato só empregasse sindicalizados (closed shop) - é uma constante luta da categoria nos mais variados locais e momentos. A Sociedad Regeneradora de Picapedreros de Mutuo Mejoramiento em Montevidéu, já em 1895, exigia do patronato tal medida. O descumprimento da medida pelo proprietário das "canteras El Minuano" (Uruguai) deflagrou uma greve (derrotada) de 8 meses (Zubillaga, Balbis, 1988, p. 87; Rodriguez Diaz, 1989, p. 81 e 88-89). Na Argentina, a greve de 1908-1909 em Tandil obteve tal reivindicação, que foi, mais tarde, violada pelo patronato em 1913 (Marotta, 1975, p. 446 e 501$)^{9}$

Quando o trabalhador migrava, deveria levar consigo um certificado de associação ao sindicato da cidade de origem. A prática transcendia os limites continentais da América do Sul, como pode-se ver pelo contato entre os canteiros do Rio de Janeiro e de Portugal. Em setembro de 1913, canteiros do Porto comunicam aos colegas do Rio de Janeiro que estes poderiam aceitar os certificados expedidos pela entidade portuguesa, ao mesmo tempo que advertiam: "aqueles que compareçam sem o competente certificado, pedimos não reconhecê-los como operários, criandolhes embaraços para que sintam a necessidade de agremiar-se." Meses antes, a entidade do Rio já recebera correspondência do Porto, Matozinhos e Leça (Portugal) comunicando que tais entidades vinham impe-

8 Ressalvadas as incontáveis diferenças envolvendo tempo, espaço, processo de trabatho e origem, tais dados sobre sindicalização seriam semelhantes aos apresentados pela pesquisa de Leôncio Martins Rodrigues (1990, p. 136 e ss.).

9 Também para os marmoristas essa reivindicação parece importante. Veja-se AVT, 30/9/1909, p. $4 ; 1 / 1 / 1914$, p. 4 e 15/2/1914, p. 2. 
dindo "de trabalhar ali companheiros que daqui foram e não eram associados do nosso sindicato." (AVT, 1/9/1913, p. 4 e 1/6/1913, p. 2). Há também registros de expedição de certificados a marmoristas portugueses emigrados (AVT, 20/6/1914).

Havia momentos em que a luta pelo controle do mercado de trabalho não se dava por meio de uma greve. Uma arma bastante utilizada é o boicote, quando os trabalhadores evitavam empregar-se em pedreiras que não reconhecessem a entidade sindical e até mesmọ recusavam-se a utilizar as pedras vendidas por esses patrões (Processo, fl. 56; Rodríguez Díaz, 1989, p. 82). Também boicotes são os apelos trocados entre os sindicatos, para que não haja migrações para onde há conflitos de trabalho. Em Ribeirão Pires (São Paulo), um boicote deflagrado em julho de 1917 pedia que o jornal da categoria em Porto Alegre publicasse o nome de "dois bandidos e iníqüos exploradores", os "infames ladrões do sangue da humanidade" (CP, 17/7/1917, p. 4). O boicote parece ser de larga utilização na categoria, a julgar pelo ocorrido em 1914 em Pelotas. Trabalhadores contratados na Argentina para o trabalho em pedreiras, ao chegarem em Capão do Leão, souberam que ocupariam as vagas de recentes demitidos por ocasião de uma greve, "e partiram no mesmo vapor que os trouxera" (OP, 4/4/1914, p. 2).

Nem sempre o patronato aceitava a exigência dos sindicatos com respeito ao controle do mercado de trabalho, pois diversas greves ocorriam com essa reivindicação. No entanto, essa é uma reivindicação tão importante da categoria, que há casos em que o próprio patronato cria sindicatos para estabelecerem contato com diferentes cidades. Um dos temas que os militantes argentinos da UGT e da FORA tiveram que enfrentar no congresso de unificação em 1914 era o estreito contato que a Sociedad de Picapedreros de la Capital mantinha com a Sociedad de Picapedreros de Tandil, organização acusada de patronal e rival da Unión Obrera de las Canteras de Tandil (Marotta, 1975, p. 531-533). Mesmo que o sindicato não fosse patronal, havia um motivo para os patrões reconhecerem o direito de controle dos trabalhadores sobre a colocação da mão de obra: o "agente" é pago para obter o maior número de migrantes, mas não pode se responsabilizar pela qualidade do trabalho efetuado. Só os sindicatos, definindo quem é oficial e quem não é, pode fazê-lo. No caso da Empresa do Calçamento em Porto Alegre, uma grande empresa que deveria responder perante o poder público pela qualidade dos paralelepípedos e calçamento efetuado, era importante confiar ao sindicato parte do controle sobre a qualidade do trabalho, 
como fez no caso dos 11 calceteiros inicialmente demitidos em 1916. Crê-se que, entre patrões e sindicatos, havia um recíproco respeito: por ocasião da greve nas pedreiras do Rio de Janeiro em 1909, os canteiros publicaram a lista dos patrões "que estão trabalhando de acordo com nós [sic]" (AVT, 30/8/1909, p. 3), ao passo que também há registros de que os patrões - pelo menos os da marmoraria - buscavam suprir sua necessidade de mão de obra junto aos sindicatos (AVT, 20/6/1914). A busca do apoio deliberado da "opinião pública" a greves da categoria foi verificada não só em Porto Alegre, em 1917, como também em Santos, em 1913 (AVT, 1/7/1913).

A legitimidade do sindicato em Porto Alegre, embora estivesse alicerçada na possibilidade efetiva de controlar a oferta de mão de obra, também estava garantida por mecanismos administrativos que, como já mencionado, envolviam punições pelo não-comparecimento a assembléias, ou mesmo a violência física. No entanto, há uma figura importante na garantia do controle do sindicato sobre a "base", que é o "delegado". Ao cargo competiria representar o conjunto da categoria em cada "pedreira ou oficina", associar os trabalhadores ao sindicato, cobrar mensalidades, zelar pelos interesses dos associados, obrigar o patronato a pagar pontualmente, autorizar a paralização do trabalho (em caso de greve) e decidir pela admissão de novos trabalhadores em cada pedreira, turma ou oficina (Processo, fls. 42-46). É por meio do "delegado" que o sindicato se contrapunha à intermediação da mão de obra por parte dos "agentes" de diferentes cidades da América do Sul. Assim, o sindicato não é, necessariamente, uma entidade externa à categoria: é pelo sindicato que passa a própria possibilidade de obtenção de emprego por esses trabalhadores em constante migração. ${ }^{10}$

Embora constantes no estatuto do sindicato, não se poderia saber se tais funções eram efetivamente exercidas, se não houvesse depoimentos corroborando a existência dos procedimentos prescritos. É o caso do depoimento do ferreiro Firmino Lopes, que pagava $1 \$ 000$ recolhidos mensalmente pelo delegado da pedreira onde trabalhava, ou o de Antônio Pires que "deixou de pagar [e] foi excluído do sindicato" (Processo, fls. 83 e 85-86). A "base" da categoria não se refere aos "delegados" por esse nome, mas por outros, mais elucidativos, que atestam a percepção do papel e legitimidade do sindicato e de seus cargos administrativos. Ao

10 Um mecanismo administrativo semelhante ao dos "delegados" em Porto Alegre já havia sido posto em prática ao Rio de Janeiro, cf. AVT, 15/7/1913. 
serem interrogados sobre a participação na greve, os trabalhadores em pedra tomavam a orientação do sindicato como uma ordem válida, transmitida por colegas que estão no exercício impessoal de cargos da entidade. Manoel Dias e seus colegas "tomaram parte na greve devido à ordem dos chefes do movimento nas pedreiras". O calceteiro Fernandes Peralvo, irmão do capataz Luiz, "foi obrigado a acompanhar a greve, ordenada pelo sindicato, por terem todos levantados [sic] o trabalho". Outro depoente, dando conta da visita de uma comissão às pedreiras, declarou "que obedecendo aos mesmos que eram dirigentes, [os canteiros] não trabalharam". Também Luis Teixeira e seus colegas "pararam o trabalho por ordem do sindicato" (Processo, fls. 69-70 e 78).

Há também um certo nível de impessoalidade no exercício das funções do sindicato - e mesmo a função punitiva da turba que atacou a turma de carneiros do calçamento - que é clara na relação de Francisco Salles com Heitor Guimarães dos Santos. Salles e seu irmão, ambos serventes e carneiros, não eram sindicalizados e foram ambos feridos no ataque de 19 de março de 1917, sendo que um deles chegou a depor ainda no hospital (Processo, fls. 165-166). Heitor Guimarães dos Santos participara da turba pela manhã, fugira após o ataque sem voltar à sede do sindicato e só pela tarde soubera da morte do calceteiro Luis da Silva. Tendo, pela tarde, encontrado um dos Salles, este, ao contrário de uma previsível vingança, compreende a impessoalidade do ataque violento pela manhã, advertindo-o: "é melhor você não trabalhar porque você pode tomar uma camaçada de pau (...) [do secretário do Sindicato, que estava] escondido e armado de pau com o fim de dar no depoente" (Processo, fl. 21).

A amostra não permite quantificar a proporção de grevistas e não-grevistas, porque isto não constou no depoimento, ou porque vários declararam estarem "enfermos" durante a greve, ou ainda pelo fato da Empresa do Calçamento determinar o lock out nas pedreiras, o que serviu como justificativa para alguns canteiros durante o interrogatório. Sem compilar esses 30 casos (afora os dois capatazes da amostra) encontramse 28 grevistas e 28 não-grevistas. Nenhum servente ou jornaleiro declarou-se sindicalizado, tampouco declarou-se em greve, ao passo que, ainda dentro da amostra, metade dos trabalhadores em pedreiras (canteiros, ferreiros, oleiros, marmoristas, encunhadores) declararam-se em greve (apenas um canteiro disse não ser grevista).

O termo-chave para o tipo de relação que a "base" mantinha para com o sindicato é "envolver-se em questões/em greves". O canteiro 
Alfredo Lages disse que "na pedreira os operários pouco se envolvem em questões do sindicato", por causa da distância que separava a sede, "na cidade", da pedreira da Serraria, por exemplo, viagem que duraria "de quatro a cinco horas". Também o ferreiro Severino Gomes "é sócio da Federação Operária porém raramente ia àquela porque não se queria envolver em questões." Já Albino Baptista, "mesmo sendo sócio do sindicato, não comparecia à sede por não dar-lhe apreço." O canteiro Joaquim Pereira de Jesus declarou "que assistiu ao 'meeting' realizado, simplesmente como um homem do público, não se imbuindo no que disseram os oradores". Por que tão poucos se "envolviam em questões", se todos os oficiais eram sindicalizados, conforme consta em diversos depoimentos? Isso ocorria não só por causa do closed shop (e a sindicalização compulsória), mas também, segundo o depoimento de Alfredo Ferreira, "para não ser mal visto entre os seus colegas de arte" (Processo, fls. $84,87,88,90-92,96,97)$.

Nas justificativas sobre a entrada ou não na greve, aparecem mais claramente a clivagem não só entre canteiros e calceteiros - o que não significaria ausência de solidariedade de uns para com outros -, como também entre a "base" e as lideranças. Máximo Gianelli declarou que os canteiros estariam em greve "até que os operários da capital também recomeçassem os seus trabalhos, prestando assim os da pedreira o seu apoio". Francisco Rodrigues é outro que "não trabalhava por os colegas da capital não trabalharem", enquanto Martim Fernandes disse que os canteiros "pararam o trabalho a pedido de uma comissão [da cidade]". Os canteiros portugueses Antonio Ribeiro e Alfredo Lages, embora fossem sindicalizados e grevistas, atribuíam aos calceteiros a responsabilidade pela agitação operária. O primeiro disse que a "a resolução [de aderir à greve] foi tomada depois que se manifestaram os operários que trabalhavam na cidade" e que "nunca ouviu discutir assuntos da greve causando esta uma grande surpresa pois foi resolvido de inopino por parte dos calceteiros", ao passo que o segundo declarou: "a greve (...) é feita pelos calceteiros, que na pedreira os operários pouco se envolviam em questões do sindicato". O canteiro espanhol Daniel Quintas, também grevista e sindicalizado, disse pouco saber da greve, "pois nesses casos trata-se secretamente" (Processo, fls. 70, 72, 84 e 87-88). 


\section{Anarquismo das lideranças e analfabetismo da categoria: implicações para o movimento operário}

A tendência da historiografia em exagerar a presença do anarquismo no movimento operário da República Velha encontraria problemas com os trabalhadores em pedra: por um lado, sua agitação tem momentos de extrema violência - não raro atribuída a anarquistas - contra os carneiros; por outro lado, ao invés do sindicato ser um espaço de exercício "libertário", sua "base" o percebe por meio de termos como "chefes", "ordens", etc. Uma solução seria aventar se a associação desses trabalhadores era verdadeiramente anarquista ou sindicalista. ${ }^{11}$ Devo dizer que, não só a associação em Porto Alegre era sindicalista (politicamente neutra, conforme declaram seus estatutos), como suas lideranças eram anaquistas (pelos registros de distribuição do folheto $O$ Ideal Libertário em assembléias da categoria - Processo, fls. 38-41). ${ }^{12}$

Duas circunstâncias permitiriam conciliar o anarquismo das lideranças com as práticas da categoria. A primeira seria a "tendência oligárquica das organizações", que atingiria também as organizações anarquistas (Michels, s/d, p. 221). Outra circunstância, que melhor caracteriza a "base" dessa categoria, é o analfabetismo, explicitado ao longo do Processo. Dentro da amostra de 88 trabalhadores, apenas 24 declarou-se alfabetizada, 30 "assinaram" seu depoimento com o polegar e 34 assinaram-no com letra trêmula, o que designaria no máximo a semi-alfabetização. Pode-se supor que o analfabetismo também fosse elevado no Rio de Janeiro, onde "os canteiros na sua maioria [eram] escassos de conhecimentos" (AVT, 13/1/1909, p. 3). Esse é um fator importante na análise da categoria, como argumenta Vilanova (1992), pois existiria uma tendência dos analfabetos em responder com dificuldade ou desinteresse questões estribadas em conceitos abstratos, mormente políticos, tais como as relacionadas com "sindicato", "partido", "eleição", etc.

São poucos os analfabetos que dão depoimentos consistentes: tal como a experiência de entrevistas de Vilanova, seriam típicas - a julgar pelos registros no Processo - as "brief responses", e a própria polícia năo

11 Discuto em Silva Jr., 1993 a impropriedade do uso do termo "anarco-sindicalismo" para a militância anterior a meados de 1920.

12 Também em Montevideo pode-se crer que as lideranças eram anarquistas, năo só por publicarem notas no jornal anarquista $L B$, como por ter sido publicado nesse jornal (edição de 20/5/1918, p. 3) o folheto O Ideal Libertário, em versão espanhola. 
parecia estar interessada nos analfabetos pois são deles os registros onde não constam idade, estado civil, eventualmente local de nascimento ou ofício. Isso nos ajudaria a matizar a penetração do anarquismo na categoria. $\mathrm{O}$ analfabeto José Gulias teria, de fato, distribuído um livreto anarquista carioca em assembléias da categoria, mas o oleiro espanhol em cujas mãos foi apreendido o tal livreto declarou que, tendo pouca instrução e desconhecendo o português, não sabia qual era $O$ Ideal Libertário (Processo, fl. 19). A própria liderança do sindicato não parecia especialmente alfabetizada, como se pode ver em um dos 5 ofícios enviados à direção da Empresa do Calçamento em 1917, no decorrer da negociação (Processo fl. 136):

Rezulveu a classe em jeral, que terminantemente para couvinar con os operarios i o Sr., para que sejão expolços os trabalhadores já citados sinco vezes, e seja adimetido o cap. gironimo também perciza que os trabalhadores ou sejão calceteiros tenham caida aberta para assim poder fazer mais alguns dias de serviço,

Não sendo tomada essa rezulução continuaremos, lutando, pela cauza, não tumando ou assumindo a responçabilidade este Syndicato pellos danos que poção aver.

Pela Comissāo isperamos

Arezuluçāo por iscripto

Talvez não fosse intenção dos anarquistas bloquear o acesso aos cargos de direção do sindicato aos analfabetos, mas isso necessariamente ocorria, quando havia a necessidade de um secretário-geral alfabetizado. Há indícios que os cargos de direção do sindicato eram sistematicamente ocupados por semi-alfabetizados, o que os levaria a recorrer a trabalhadores de outras categorias para eventos como comícios em praça pública (onde falaram um tipógrafo e um caixeiro), ou mesmo para enviarem ofícios à Empresa do Calçamento, alguns dos quais escritos pelo mesmo caixeiro Oscar Torelly de Araújo e Silva, que o fez "a pedido da classe" (Processo, fl. 75).

Se era difícil aos analfabetos e semi-alfabetizados compartilhar das elaborações políticas dos anarquistas, ${ }^{13}$ ocupar cargos de administração ou fazer discursos, havia um caminho mais fácil para participar ativa-

13 Sobre a rotatividade no secretariado das assembléias: "[o sindicato] é presidido por qualquer operário aclamado na sessão (...), tendo sempre assim outro presidente, não havendo portanto responsáveis"; ou então "é provável que o sindicato tenha um presidente que o declarante não conhece" (Processo, fls. 84 e 95-96). 
mente da militância sindical, conforme observou Vilanova (1989, p. 116): ser membro da "tropa de choque" da entidade. Ao contrário do que se poderia pensar, vinculando o anarquismo à violência de seu desejo revolucionário, o ápice da participação de analfabetos na militância desse sindicato "libertário" seriam os ataques tumultuosos de grevistas a carneiros e não, por exemplo, as violências impessoais da dinamite (que era, aliás, material rotineiro no trabalho nas pedreiras, mas cujo uso em greves da categoria não deixou, salvo engano, quaisquer registros).

Talvez possa ser colocada a questão, como um plano para novas pesquisas: as greves turbulentas tenderiam mais a ocorrer em categorias com muitos analfabetos? Ou ainda: categorias com muitos analfabetos tenderiam mais a substituir a organização sindical por tipos de "negociação coletiva através do tumulto"? (Hobsbawm, 1981, p. 26).

\section{Considerações finais}

Vilanova (1989, p. 119) preocupa-se com a história oral dos analfabetos porque eles estariam "absent from all written documentation save statistics", mas procurei demonstrar, estimulado pelas preocupações de Wolfe, que processos criminais podem ajudar a revelar algo de trabalhadores comuns, alfabetizados e analfabetos, envolvidos ou não em greves, contribuindo substancialmente para a análise da atividade sindical. Creio, no entanto, que isso só foi possível devido a uma mudança de perspectiva, também preconizada por Wolfe, no sentido de verificar hiatos (melhor: gaps) entre os líderes e a "base" sindical. A crítica que os historiadores costumam fazer aos limites do anarquismo no movimento operário não escapam a um certo tom celebratório do tipo "flores aos rebeldes que falharam", esquecendo-se que os sindicatos são associações de dominação (no sentido weberiano), independente de seus cargos de direção serem ocupados por "amarelos" ou anarquistas. Só essa perspectiva nos permitirá fazer uma "história dos de baixo" do movimento operário da República Velha, na qual, por mais estranho que isso pareça, as lideranças operárias, mesmo as anarquistas, estão também "em cima" - onde, como de costume, os pesquisadores colocam apenas a classe dominante e/ou o Estado. 


\section{Bibliografia e fontes citadas}

$\mathrm{AF}=$ A Federação, Porto Alegre, 1917 e 1926.

A Luta, Porto Alegre, 1906-1911.

A Luta, Pelotas (Rio Grande do Sul), 31 maio 1916, p. 4.

AVT = A Voz do Trabalhador. Órgão da Confederação Operária Brasileira. Coleção

fac-similar de 71 números 1908-1915. São Paulo: Imprensa Oficial do Estado, 1985.

BRASIL. Ministério da Agricultura, Indústria e Comércio. Recenseamento do Brasil -

Indústria. [1920]. Rio de Janeiro: Tipografia da [Diretoria Geral da] :Estatística, s/d.

p. $162-165$.

$\mathrm{CM}=$ Correio Mercantil, Pelotas (Rio Grande do Sul), 1914.

$\mathrm{CP}=$ Correio do Povo, Porto Alegre, 1916-1918.

D'ELIA, German, MIRALDI, Armando. História del movimiento obrero en el Uruguay.

Desde sus origenes hasta 1930. Montevideo: Banda Oriental, 1986.

Diário de Notícias, Porto Alegre, 9 ago. 1927.

DP = Diário Popular, Pelotas (Rio Grande do Sul), 1914.

FRENCH, John D. Practice and ideology: a cautionary note on the historian's craft.

Hispanic American Historical Review s/l: Duke University, vol. 71, n. 4, nov. 1991. p. 847-855.

GITAHY, Maria Lúcia Caira. Ventos do Mar. Trabalhadores do porto, movimento operário e cultura urbana em Santos, 1889-1914. São Paulo: UNESP, 1992.

HOBSBAWM, Eric. J. Os destruidores de máquinas. Os trabalhadores, estudos sobre a

História do Operariado. Rio de Janeiro: Paz e Terra, 1981 p . 15-31.

LB = La Batalla, Montevideo, 1915-1918.

MACHADO, Carlos. História de los orientales. Montevideo: Banda Oriental, 1972.

MAROTTA, Sebastián. El movimiento sindical argentino. Su génesis y desarrollo. 2. ed. Buenos Aires: Libera, 1975.

MICHELS, Robert. Os partidos politicos. s/l: Senzala, s/d.

Notícia. Porto Alegre, 2/4/1918.

$\mathrm{OD}=O$ Diário, Porto Alegre, 20 mar. 1917. p. 3.

OP = Opinião Pública, Pelotas (Rio Grande do Sul), 1914.

O Sindicalista, Porto Alegre, mar./1921.

PARANÁ. Secretaria de Estado da Indústria e do Comércio. Minerais do Paraná S.A.

Gerência de Fomento e Economia Mineral. Paralelepípedos e alvenaria poliédrica. Manual de utilização. s/l: s/ed., 1983.

PASSOS SOBRINHO, Josué Modesto dos. Migraçōes internas: resistências e conflitos (1872-1920). Cadernos de Estudos Sociais. Recife, vol. 8, n. 2, p. 235-260, jul.-dez. 1992.

PEREIRA, Miguel. Esboço histórico da Brigada Militar do Rio Grande do Sul. 2. ed. Porto Alegre: Livraria Americana, 1950. v. 2.

PORTO ALEGRE. Relatório da Diretoria de Obras do ano de 1897.

PORTO ALEGRE. Relatório da Diretoria de Obras da Intendência Municipal de Porto Alegre. $2^{\circ}$ semestre de 1916 e $1^{2}$ semestre de 1917.

PORTO ALEGRE. Relatório e projeto de orçamento para o exercício de 1916 apresentado ao Conselho Municipal na sessão ordinária de 1915. Porto Alegre: Oficinas Gráficas d'A Federação, 1915. 
Processo $=$ Processo-crime n. 856. Réus: Ângelo Cavanellas e outros. Maço 53, Estante

2. 1917. Tribunal do Júri. Arquivo Público do Estado do Rio Grande do Sul.

Rebelião, Porto Alegre, 14 mar. 1917.

RIO GRANDE DO SUL. Transferência ao Estado dos contratos da "Compagnie Française du Port de Rio Grande do Sul. Porto Alegre: Oficinas Gráficas d'A Federação, 1920.

RODRIGUES, Edgar. Alvorada Operária. Rio de Janeiro: Mundo Livre, 1979.

RODRIGUES, Leôncio Martins. Trabalhadores de uma indústria automobilística: perfil social e participação sindical. Partidos e sindicatos. São Paulo: Ática, 1990. p. 105-151.

RODRÍGUES DÍAZ, Universindo. Los sectores populares en el Uruguay del Novecientos. Primera parte (1907- 1911). Montevideo; Compañero, 1989.

SILVA Jr., Adhemar Lourenço da. Anarquismo e movimentos sociais: uma tipologia de suas relaçōes. Cadernos do CPG-História. Porto Alegre, CPG em História-UFRGS, n. 8, dez. 1993, p. 3-23.

— . "Povo! Trabalhadores!": tumultos e movimento operário. (Estudo centrado em Porto Alegre, 1917). Porto Alegre, dissertação de mestrado em História-UFRGS, 1994a.

.Canteiros, calceteiros, picapedreros: migracōes e lutas sindicais no Cone Sul. Anais do Encontro de História e Geografia do Prata. Instituto Histórico e Geográfico do Rio Grande do Sul. 1994b. (no prelo).

VILANOVA, Mercedes. Anarchism, political participation, and illiteracy in Barcelona between 1934 and 1936. The American Historical Review. Vol. 97, n. 1, feb. 1992, p. $96-120$.

WOLFE, Joel. Anarchist ideology, worker practice: the 1917 General Strike and the formation of São Paulo's working class. Hispanic American Historical Review. s/l: Duke University, vol. 71, n. 4, nov. 1991a. p. 809-846.

— Response to John French. Hispanic American Historical Review. s/l: Duke University, vol. 71, n. 4, nov. 1991b. p. 856-858.

- Social movements and the State in Brazil. Latin American Research Review. Vol, 28, n. 1, 1993a, p. 248-257.

-Working women, working men. São Paulo and the rise of Brazil's industrial working class, 1900-1955. Durham: Duke University, 1993b.

ZUBILLAGA, Carlos, BALBIS, Jorge. Historia del movimiento sindical uruguayo. Tomo I: Cronologia y fuentes (hasta 1905). Montevideo: Banda Oriental, 1985.

sectores populares (hasta 1905). Montevideo: Banda Oriental, 1988. 
Tabela 1

Profissão e nacionalidade declaradas

\begin{tabular}{|l|c|c|c|c|c|c|c|c|}
\hline \multicolumn{1}{|c|}{$\begin{array}{c}\text { Profissão } \\
\text { declarada }\end{array}$} & $\begin{array}{c}\text { (Nascidos no } \\
\text { Rio Grande } \\
\text { do Sul) }\end{array}$ & $\begin{array}{c}\text { Total de } \\
\text { Brasileiros }\end{array}$ & $\begin{array}{c}\text { Portu- } \\
\text { gueses }\end{array}$ & Espanhóis & Uruguaios & Outros* & $\begin{array}{c}\text { S/registro de } \\
\text { nacionalidade }\end{array}$ & Total \\
\hline Canteiros & 0 & 2 & 17 & 13 & 1 & 0 & 2 & 35 \\
\hline Calceteiros & 4 & 6 & 0 & 2 & 0 & 1 & 2 & 11 \\
\hline Pedreiros & 1 & 1 & 1 & 1 & 2 & 0 & 0 & 5 \\
\hline $\begin{array}{l}\text { Serventes e } \\
\text { jornaleiros }\end{array}$ & 5 & 6 & 0 & 2 & 0 & 1 & 1 & 10 \\
\hline Ferreiros & 1 & 1 & 2 & 3 & 0 & 0 & 1 & 7 \\
\hline Encunhadores & 0 & 0 & 3 & 0 & 0 & 0 & 0 & 3 \\
\hline Marmoristas & 0 & 0 & 0 & 1 & 0 & 0 & 0 & 1 \\
\hline Oleiros & 0 & 0 & 0 & 1 & 0 & 0 & 0 & 1 \\
\hline Mineiros & 0 & 0 & 0 & 1 & 0 & 0 & 0 & 1 \\
\hline Capatazes & 0 & 1 & 0 & 1 & 0 & 0 & 0 & 2 \\
\hline S/declaração & 1 & 2 & 5 & 1 & 0 & 0 & 4 & 12 \\
\hline Totais & 12 & 19 & 28 & 26 & 3 & 2 & 10 & 88 \\
\hline
\end{tabular}

* Um alemão e um italiano. 


\section{Gráfico 1:}

Nacionalidade declarada dos trabalhadores em pedra $($ Total $=78)$

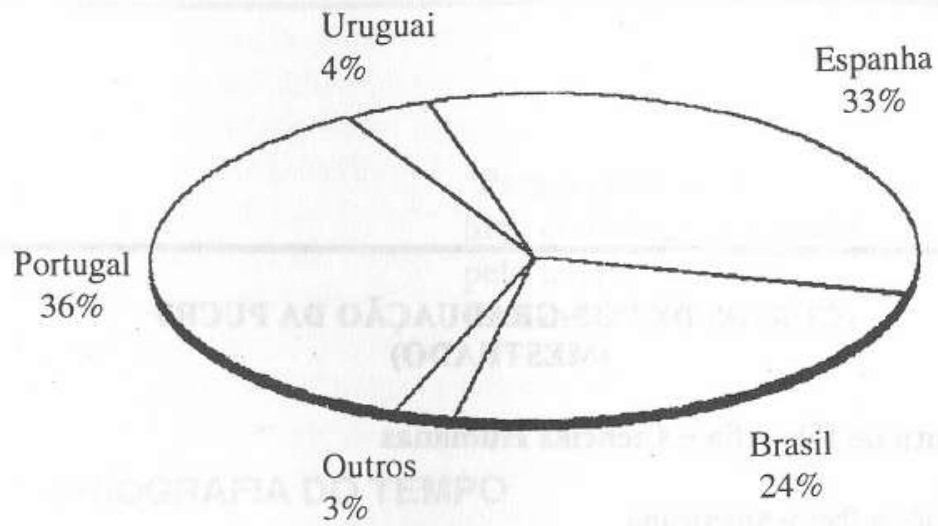

Gráfico 2:

Idades declaradas dos trabalhadores em pedra $($ Total $=83)$

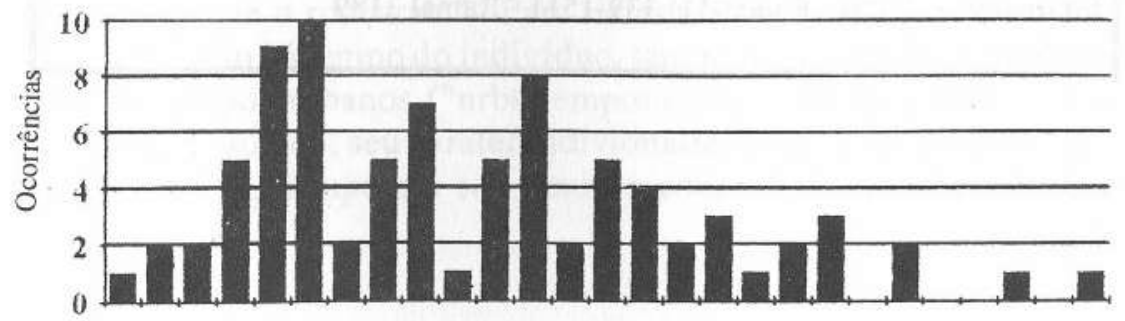

$19202122232425262728293031323334353637383940 \ldots \ldots .50 \quad \ldots \quad 63$ Idade 